\title{
Ad5-survivin-transduced Autologous Dendritic Cell Vaccine
}

National Cancer Institute

\section{Source}

National Cancer Institute. Ad5-survivin-transduced Autologous Dendritic Cell Vaccine. NCI

Thesaurus. Code C128860.

A cell-based cancer vaccine containing autologous dendritic cells (DCs) that are transduced with a replication-deficient adenovirus type 5 vector (Ad5) encoding a mutated form of the tumor-associated antigen (TAA) survivin, with potential immunostimulatory and antineoplastic activities. Upon administration, Ad5-survivintransduced autologous DC vaccine may elicit an immune response ag ainst cancer cells expressing survivin by activating cytotoxic T-cells (CT Ls). This leads to an induction of cell death in survivin-positive tumor cells. Survivin, a member of the inhibitor of apoptosis (IAP) family of proteins, may be upregulated in certain tumor cell types and plays a key role in tumor cell growth and survival. 